\title{
The Wandering Jew in Novels of Jane Austen: The Pursuit of an Organic Whole in Romanticism
}

\author{
Rebecca Kenseh Madaki (Corresponding author) \\ Department of English Language and Literature \\ School of Foreign Languages \\ Northeast Normal University, No.5268 Renmin Street \\ Changchun, Jilin Province 130021, China \\ E-mail: rkenseh@yahoo.com \\ Zeng Li \\ Department of English Language and Literature \\ School of Foreign Languages \\ Northeast Normal University, No.5268 Renmin Street \\ Changchun, Jilin Province 130021, China
}

Received: 21-03-2014

doi:10.7575/aiac.ijalel.v.3n.5p.104
Accepted: 08-05-2014

Published: 01-09-2014

\begin{abstract}
Austen's fictions may or may not set out to express the framework of imagery that projects the division of beings into four levels as enumerated by Northrop Frye in his Essay "The drunken boat: the revolutionary element in Romanticism", her works, like the Romanticism poets are greatly influenced by this framework. This framework is found in the imagery of pre- Romanticism poetry and is the basis for the conflict between the Romanticism and the preRomanticism one despite their affiliation and similarities. Frye expounds the influence of this framework in the poetic garden of imagery in Romanticism, this work attempts to expand the influence in the prose garden of Austen's symbolic expressions. Austen uses symbolism to interpret the structure of beings and their station, the concept of alienation, the journey, and the quest and finally the formation of an organic whole; the superb inter-change of the masculine and feminine domain in metaphoric representation excels Austen's works within Romanticism expressions.
\end{abstract}

Keywords: Wandering, Jew, Organic, Whole.

The Wandering Jew in Novels of Jane Austen: The Pursuit of an Organic Whole in Romanticism.

\section{Introduction}

The politics that dominate the movement and ideology of Romanticism can by association with era, principle, action, space or category establish its authority and propel its application. In the late seventeenth and early eighteenth century, literature was gradually moving away from classical or religious affiliations to circular thematic concerns, the consequence of which a movement that was later called Romanticism began, and its ideology began to spread, critics like Northrop Frye; M. H. Abrams; Charles Rosen; Arthur O. Lovejoy just to mention a few, place the era of the Romanticism movement around the late seventeenth and early eighteenth century.

At the time, many things happen in the religious conventions, the political arena, the rise and fall of revolutions, wars, betrayals just to mention a few. The Romantics were emerging and writing about these things. Many critics assert that the most predominant themes that occupy this period were: One: The exultation of consciousness, placing imagination at the center of all creativity. Two: The moral dilemma that man has to battle with. Three: A call to return to nature, (the marriage of man to nature) and then, a return to the original state of man in the Garden of Eden before the fall. These themes occupy the works of Romantic poets like Lord Byron, William Blake, William Wordsworth, John Keats, Percy Shelley, Samuel Taylor Coleridge and the Romanticism canon was centered on the writings of the poets and the world of imagery. According to Rosen (2006) "Abrams expounds ideas in Romantic poetry that lose all vitality when reduced to plain prose that cats and dogs can read" (p. 27), Frye opines that Romanticism is a selective term projected through the language of imagery and is difficult to adapt to the novel (p. 122, 126). Later Romanticism and Romanticism critics expand the Romanticism canon to include many things and Romanticism even among the poets have different meaning and applicability that Author Lovejoy's (2006) celebrated assertion that "The word romantic has come to mean many things that, by itself, it means nothing" (p. 38) becomes important, therefore his suggestion of the use of the word Romanticism in the plural is essential. Frye (2006) on the other hand believes that because the Romanticism has an acknowledged center of historical gravity, it should not be subjected to ideas, and he exults the power of imagery above that of ideas (p. 123). The thematic, subject, nationality, form, style, application and era of Romanticism keep expanding and the plurality of Romanticism becomes inevitable and it becomes impossible to define or give any one meaning to the term "Romanticism" in isolation. The term therefore becomes subjective and is used in application or 
context. Helen Thomas in her essay "Romanticism and Abolitionism" trades the Romanticism canon in different markets with extensive range of coverage. She rains themes of gender and sexuality, liberalism, self consciousness, slavery, emancipation, class, racism, imperialist practice and international trade. She mentioned scholars like Mary Jacob, Anne Mellor, amongst others who expanded the canon to include "feminist literary history". She features her points on the racial and gender slavery and the emancipation and abolitionary Romanticism.

Despite critic's enthusiasm to isolate the male poets as the main and perhaps the only body of the Romanticism Movement and to limit the Romanticism canon to the power of imagery, it has remained a wish. Austen, though a novelist seems to excel in conveying Romanticism ideals through the available vehicle of symbolism with success. Over and over, the Romanticism canon has carried writers who lived through the same era and connect to the same thematic concerns, whether they sit at the middle of the canon or at the edge, the boat of poetic phraseology and that of fictional penmanship sails to the same romantic shore. Their Romantic bond is not voluntary. Frye (2006) had mentioned in the essay "The drunken boat: the revolutionary element in Romanticism" that "though selective, Romanticism is not a voluntary category" (p. 123).

Austen's affiliations to the Romantic tradition is not deliberate neither is it a voluntary category. It is not a subject of debate in this work but just to mention by passing that she does not write to be (come) a Romanticism writer. The focus of this study is not on the question of whether Austen belongs to the Romanticism category or not, or how well she interprets the Romanticism ideology because that has already exhausted itself in criticism and has become a cliché to mention. William Deresiewicz (2004) opines that critics have tried to:

Identify Romantic characteristics in Austen's work as a whole. ... Others have pointed to specific novels or more commonly, specific characters, scenes, or elements, as displaying typically Romantic attributes. But those line of investigations have yielded valuable insights, they imply no more than a Zeitgeist kind of affinity (p. 3).

That may be true, but the insights provided creates a solid foundation for Austen's works within the land of romanticism and the need to establish any form of affinity is filled and Austen's works can be treated without doubt as belonging not only to the Romantic era but to the Romanticism movement though her expressions are outside the great worlds of imagery.

\section{Analysis}

This work will present Austen's insight through her symbolic touch, into the Romantics' ability to shift the framework of imagery and symbolism, from the outside model designed by God or science or other models outside of man for man to follow to the imaginative creative power of man (man is the creator of all things) and the model to follow is in the inside of man shaped by experience. Frye expounds the influence of this framework in the poetic garden of imagery, this work attempts to expand the influence in the prose garden of symbolic expressions.

The revolutions in the political front shifted focus to the religious conventions that greatly influenced the writings of that time and capture the poetic and prose community that flourished including Austen's writings; the Christian religious canon that reflects the order of being, the journey of mankind through the different faces of life and the mythic realities among other themes that flourish within and around it, is the creative fuel that ignites the Romanticism fire that burned through their thoughts and writings. Deresiewicz (2004) again reveals

But something else happened during those twelve years ...to have a profound impact on Jane Austen's art. Her long period of silent growth ... coincided with and can to a considerable extent be attributed to the most significant literary event of her lifetime: the flowering of the poetic movement that later became known as British Romanticism (2).

Irvine (2007) opines that

It is possible to see Austen as taking part in the cultural shifts that characterize her era and that were also acted out by the romantic poets. For example, their location of poetry in something like the place of religion makes a new claim for the autonomy of their writing from other less elevated types of writing, as 'literature' in a new, restricted sense. Austen too can be seen to be reaching for something like this high status for her own work (p. 28).

Taking of Hazlitts' subjects, M.H. Abrams (2006) confirms the time of the Romanticism flourish that Frye had placed around 1790 to 1830 which is also around the time Austen's works emerged “... the early 1790 s and 1825 - coincides with what literary historians now call Romantic period” (p. 74). Hazlitts' opinion in 1793 is that:

"schemes for a new society "of virtue and happiness" had been published "in plays, poems, songs and romances - made their way to the bar, crept into churches ... got into the hearts of poets and the brains of metaphysicians ... and turned the heads of almost the whole kingdom" (qtd. in Abrams 2006, 77). Abrams believe that is true for all who read the books of that era. When Abrams talks of that era and defines Romanticism, though he specifically mentioned poets, Austen's works involuntarily falls within the category. He talks of the influence of the story of creation and formation of the world we now live in:

Romanticism is no one thing. It is many very individual poets, who wrote poems manifesting a greater diversity of qualities; it seems to me, than those of any preceding age. But some prominent qualities a number of these poems share, and certain of these shared qualities form a distinctive complex which 
may, with a high degree of probability, be related to the events and ideas of the cataclysmic cominginto- being of the world to which we are by now becoming fairly accustomed (p. 76).

Austen's works paint a symbolic picture of the world with precision that conveys Romanticism thoughts on the "events and ideas" that structured on the "cataclysmic coming - into - being of the world"

Frye (2000) in his anatomy of criticism talks of the influence of Christianity. "If Christianity had not been both an imported myth and a devourer of rival ones, this phase of Western literature would be easier to isolate. In the form in which we posses it, most it has already moved into the category of romance." (p. 34)

M. H. Abrams also talks about the influence of the biblical prophecies on the writings of Romantics of the 18th century who lived through the American and French revolutions. These revolutions brought with it 'hopes and terrors'. These civil wars and the experiences according to him, brought about the use biblical allusions to construct political reality since the socio - political language has been polluted.

[They] looked upon contemporary politics through the perspective of biblical prophecy. Many preachers and religious nonconformist preached about Christ as a revolutionary and later they turned to the book of revelation of the apocalyptic violence. Typically this mode of romantic vision fuses history, politics, philosophy and religion into one grand design, by asserting providence - or some form of natural teleology - to operate in the seeming chaos of human history so as to effect from the present evil a greater good (p. 83)

Rosen (2006) explains that "In 1789-1790 ... the betrayal of the revolution was a traumatic blow to the generation that had lived through it and was young enough to hope ... the brief appearance of what Hazlitt called "romantic generosity" dominated politics and art" (p. 20) IV), He affirms the religious affiliations "After the failure ... of the political and social dream of 1789 , the Romantic program presented itself in increasingly religious terms ... revival of medieval imagery" (p. 20). The Romantics' use of the biblical enterprise to polish the moral, cultural, social political, economic and every other sphere of thematic discourse in literature cannot be overemphasized. Frye summarizes and enumerates the framework of imagery as it affects the whole journey of mankind through life, and Abrams calls it "the circuitous journey".

\section{The Framework}

Frye categorizes the framework into four levels, and spells out the conflict it generates between the pre- Romanticism and the Romanticism writers. He focuses on the structure of imagery.

1. The first level is 'Heaven',

2. The second is 'the human level',

3. The third is 'the physical level'

4. The forth level is the level of 'sin, death, and hell'.

The highest level is heaven, the place of the presence of God ... the two levels of the order of nature, the human and the physical level. The order of human nature, or man's proper home, is represented by the story of the Garden of Eden ... Man is no longer in it, but the end of all his religious, moral, and social cultivation is to rise him into something resembling it.

He explains that the world man now resides in, is the world of the plants and animals and unlike the plants and animals, man is not adjusted to this world. He further elucidates that "man is confronted from birth with a moral dialectic, and must either rise above it to his proper human home or sink below it into the forth level of sin, death and hell." (p. 124)

The conflict between the pre- Romanticism and the Romanticism poets is demonstrated in the reflection of the model of use and the interpretation and placement of the above framework: For the pre- Romanticism poets the "appropriate metaphors of imitation are visual and physical ones, and the creative powers of the poet have models outside of him" (Frye 2006, 127), the Romanticism poets on the other hand, have the source of their creative power in the mind with the external world being an extension or the reflection of the inner creation. In this internal world, "reality is brought into being by experience" (Frye 2006, 128). Abrams studying Wordsworth's The Prelude "prospectus" to The Recluse reveals his aim at the restoration of paradise

And the restoration of paradise, as in the book of Revelation, is still symbolized by a secret marriage. but the hope has shifted from the history of mankind to the mind of the single individual, from militant external action to an imaginative act; and the marriage between the Lamp and the New Jerusalem has been converted into a marriage between the subject and the object, mind and nature, which creates a new world out of the old world of sense. (p. 90)

Frye (2006) explaining the Romanticism view of the internal and the external world, he leans heavily on Rousseau representative assumption that "civilization was purely human artifact; something that man made and could unmake, could subject to his own criticism and was at all times responsible for. Above all, it was something for which the only known model was in the human mind.' (p. 127)

While the pre- Romanticism writers find it easy to place God at the center of creation with his home in heaven which is above the universe (the animal and vegetable world we live in) and hell below, the Romanticism writers believe that all creation, including the formation of gods and all that goes with the mythic existence is in the imaginative creation of man. Abram says 'For Wordsworth, mind or spirit here has become largely secular; God appears - if at all - only as 
within man's mind and Abrams recalls a rich seventeenth - century tradition that resists any attempt to place God outside ourselves' (qtd. Rosen 2006, 21) T. E. Hulme believes that the Romantics' don't believe in god so they say that man is god. For Austen, the symbolic representation of God in her works is in the "Father" figure.

The symbolic presentation of the man, the woman and the home, and the woman's journey from her maiden days to marriage forms the structure of Austen's works and projects the style of her Romanticism discourse.

The society that Austen depicts in her narration is a balanced society where the family, societal structure, interactions, hierarchy, duties, responsibilities, and religious, political, social, and cultural cultivation of the people are clearly spelled out. The narration portrays historical and cultural phenomena within the Georgian middle class English society of the late seventeenth and early eighteenth century, the time when Romanticism flourished. The conflicts of daily life struggle, class and gender patterns, love and relationships, family and societal interactions, achievements and failures are patterned into a realistic depiction of the struggle of humanity. The struggles that deepened Austen's concern however are the concepts of alienation (maturation, self consciousness) and integration (a return to the original state of organic unity that can only be achieve through the union of man to nature, woman to man, subject and object). These are illustrated in the struggles that emanate from the separation of self from self. The self- consciousness of the woman of which the effect is her metaphoric removal from Eden and her placement and struggle in a world she does not understand and cannot be fully adapted to. The moral dilemma she faces and her ability to rise above it to achieve her own Eden (paradise) or to sink below it to the world of sin and death is enumerated, though the sinking below is not the subject of discussion.

\section{Analysis}

Austen's depiction of family (home) circle is symbolic of the concept of infinity of the framework as a whole. In the realm of her symbolic representation, the home or the family is a symbol of the Garden of Eden or the lost paradise, the father figure a symbol of God, while the Son figure is a symbol of nature. The woman symbolizes mankind and the period where she is removed from Eden to this world (the vegetable world), the period of alienation is symbolized by maturation or what Austen calls coming out (Mansfield Park 502)

In the metaphoric representation of the first and forth order and where it is situated, the later romantic poets unlike the early romantics like Dante and Milton find it difficult to place these orders, Frye mentioned early poets like Dante, who puts the order of nature from top to bottom, Milton places heaven and hell outside the cosmos, in a kind of absolute up and down and Newton's ups and downs become even more confusing. He also talks of Romanticism poets like Blake and Coleridge, While Blake does not see God as "up there", Blake suggest that all that exist up there is a set of geometrical diagrams and "God . . . is not a mathematical diagram." Blake's point according to Frye (2006) is that "admiring the mechanisms of the sky leads to establishing human life in mechanical patterns too" (p. 125), "we have found, then, that the metaphorical structure of Romantic poetry tends to move inside and downward instead of outside and upward, hence the creative world is deep within, and so is heaven or a place of the presence of God" (p. 131).

Frye went further to remind us of the similarity between Blake's god and that of the other Romantics like Shelley's Jupiter, Byron's Arimanes, the lord in the Prologue to Faust amongst others. He also mentioned hardy's Immanent Will and Orwell's Big Brother, God in Romanticism is a creation of the individual artist. For Austen, therefore, "God" is "the father figure". The man symbolizes God when he moves from the position of a lover, a seducer or just a husband to the position of power as a father figure, an instructor, protector, provider and leader of his family. Whether he is an affectionate, indulgent father like Mr. Woodhouse and Mr. Bennet or like Sir Thomas that is strict or like General Tinley that is a dictator or like Mr. Elliot that is complacent, he still is God. God therefore becomes alive for all generation. He does not exist within or outside of man, he is man. He directs his household and it is expected that his authority is not challenged. God, who is the father therefore creates and establishes his Eden with rules that govern it. For the pre-Romanticism writers, the Garden of Eden or the lost paradise is somewhere "up there", for the Romanticism writers it is within the consciousness of man. "In Blake this world at the deep center is Jerusalem, the city of God that mankind, or Alboin, has sought all through history without success because he has been looking in the wrong direction, outside." (Frye 131), "for it is clear that this "new world" is an aspect of the re-created universe there represented as "a simple produce of the common day," if only we learn to marry our mind to nature "in love and holy passion" (Abrams 2006, 96), for Austen as mentioned earlier, in Austen's symbolic metaphoric representation, Eden or the lost paradise is the family or home front, which is inherently the creation and responsibility of mankind.

The garden therefore is the reincarnation of families for generations and can only be extinct without the presence of "The Man" in it either as "God" or as "Nature". The presence of the male figure as God or as Nature therefore establishes an Eden that can be cultivated.

Austen begins the narration of all her works with the introduction of a home front or family in one way or the other. In Sense and Sensibility, she introduces the Dashwood family, In Pride and Prejudice, the Bennet family, In Mansfield Park, the Bertram family, In Emma, woodhouse family, in Northanger Abbey, the Morland family and Persuasion, the Elliot family. There are other families mentioned in the novel but the ones mentioned above are families of the heroines. The centrality of Austen's narration is the family circles, either an already established one or the one about to be entered into. These families have the man as the initiator and leader. On the death of Mr. Dashwood without a male heir from his second wife, her Eden was extinct, same also with the family of the Bates in Emma and that of Mrs. Smith in Persuasion. In the Bennet family however the father threatens what will happen to his wife and the girls on the occasion 
of his death. "It is from my cousin, who, when I am dead, may turn you all out of this house as soon as he pleases." (p. 271).

This first Eden (home) where the woman was situated is not of her choice and she has no part in the construction. The father figure is in charge therefore, he metaphorically sends her "out" of that Eden when she "falls". The "fall" is the symbol of maturity and the sending "out" of Eden is the metaphoric symbol of the period when the young girl is introduced to the world of men, where she begins her journey, it is a period of alienation. The woman at this point possesses knowledge of herself, her womanhood. The Romanticism poets and critics have different names for this period. According to Rosen, the Romantics follow Rousseau's idea that 'self-consciousness is a disease, an alienation of oneself from oneself, a loss of unity', in Schelling's words the very act of thinking is 'a spiritual sickness" "This division of the self is, indeed, a fall from grace; the very act of reflection is the knowledge of good and evil. ... The fall from grace continuously re-enacted at every moment is the condition of life. Alienation ... is synonymous with existence" (Rosen 2006, 28), Hartman calls it a "disease", Hartman also describes this period as "maladies ... [of] the adolescent mind" or "the period of transition" or "the chamber of maiden thoughts" he says "these maladies are for the adolescent mind ... they especially affect the transition from adolescent to maturity. ... Whatever changes the mind must undergo, and [he asserts] that it is the Romantics who first explored the dangerous passageways of maturation" ( $p$. 136), the pre- Romantics on the other hand believe that man is originally a primitive and becomes salvage only after his fall. Austen calls this period "coming out" or simply "out". This period is not achieved by external factors or by the fall or sin of the woman as the naïve theological believe connotes Hartman (2006) describes "the link between consciousness and self-consciousness, or knowledge and guilt, is already expressed in the story of the expulsion from Eden. Having tasted knowledge, man realized his nakedness, his sheer separateness of self (p. 138). In Austen's stories, knowledge and nakedness are characteristics of the inward construct, it is a natural part of the process of human existence, of maturation and Austen was bold enough to acknowledge and explore it. Austen's heroines evidently go through the process of self consciousness, of nakedness and of separation and alienation.

It is a necessary part of her journey, of her experience if she is to achieve a state of "organic" wholeness. She has to be removed from her first Eden or paradise where she lived. She has to be born into this world; she then has to undergo a journey that will enable her achieve her "organic" state or unity that journey is not physical; it is a metaphoric journey, so also is her removal, they are metaphorical representation of the story of the Garden of Eden. The woman is faced with moral dilemma and difficult choices to make in a world she does not fully understand and is not adapted to, this journey for the Romanticism poets is best illustrated in the metaphor Abrams calls the:

"Circuitous journey" the vision of a regained paradise, a return through alienation to an original state of "organic" unity, now made transcendent by incorporating and resolving the contradictory forces of the journey itself. The circle is therefore generally spiral, a return to the same point on a higher level" (qtd. in Rosen 2006, 21)

This place, world or condition the woman is not accustomed to it. 'The third level ... which man is born into it but which is not the real world of human nature. Man's primary attitude to the external physical nature is thus one of detachment' (Frye 128). Hartman (2006) explains that one of the themes that best express her journey through this world is the 'perilous nature of consciousness' and this theme has been expressed in diverse ways and has been central to literature since the Romantic period is 'the solitary' or 'the wandering Jew', he points out that "These solitaries are separated from life in the midst of life, yet cannot die' (p. 139), for knowledge, and still more for imagination, the journey within to the happy island garden or the city of light is a perilous quest" (Frye 2006, 132). For the romantics this journey extinct in death or other terminal end as projected by Hartman (2006) "it is, ultimately, consciousness that alienates them from life and imposes the burden of a self which religion or death or a return to the state of nature might dissolve." (p. 139)

Austen presents the coming "out" as the woman is born into this world, (sent out of the her original home), she has not been to this world, she under the direct supervision of her father (God) in her first Eden, she reaches a point of maturity (self-consciousness) and therefore cannot remain in Eden, she needs to be separated, sent out of Eden. She needs to be cured of the "disease" or "maladies" as Hartman calls it and the only way to do that is for her to be separated or removed from the garden and for her to undergo this "solitary" or "circuitous" journey, Her period of alienation thus begins, she begins the search, the perilous journey to find her to borrow from the words of Ashley Tauchert (2005) "full identity", to find nature and be united with nature for it is only then that she can achieve her paradise at a higher level like Wordsworth where she will then be able to take charge of her Garden.

The most common occurrence in all her works is the "weddings". The moral cultivations of her heroine(s) led to a fulfilling marriage. The heroine(s) is faced with challenges of her choice of a man, she strives against such challenges, goes through pains and difficulties but arrives at the ultimate goal, which is a successful marriage, of which she desires and chooses. The bold projection of the feminine domain pushes critics to project her works within romance that is influence by heterosexuality and the female exquisite and sensitive image, the woman, who is the central character therefore, for many critics, represents the feminine Zone and her placement and experience project the subject of subjugation, oppression and emancipation central to feministic pursuit.

Alan Richardson asserts that 'critics have paid careful and rewarding attention to the education, socialization, and cultural predicaments of her heroines' (p. 302), Tauchert (2005) opines that Austen's works "is a meditation on the peculiar tenderness of romance ... in the resolutely feminized realm of the love story"(Xi) and "At the heart of Austen's feminine romance narratives ... at its aesthetic high-point, the feminine romance can be read as a kind of cultural day- 
dreaming common to women ... concerns the splitting of the subject and quest for the object." (Xii); and Paula Byrne in her introduction to Jane Austen's Emma argues that 'she was a champion of female politics, a subversive writer engaging with the feminist ideology of her time.' (2004: introduction) Wainwright opines that Austen excels in her depiction of the 'highs and lows of sexual dynamics' (2007, 27).

A more intimate romance with the works of Austen is necessary for the understanding of the delicate nature of her symbolism and expression and the unique way she presents the concept of the order of nature and the division of beings and conflicts that surround the subject of placement and representation, and of alienation and integration.

The heroines have different challenges but the one thing that is common is that they seek to marry and their marriages promote them and they are seen to be happily cultivating their home. At this point, for the purpose of this study, I will mention the heroine of each novel and subsequently use "heroines" for collective expression, and in the case of emphasis I will mention the particular heroine. This does not allow for the assumption of a collective responsibility in Austen's style of characterization. Her heroine(s)'s challenges are strictly individualistic even if the experiences are similar. The following characters are categorized as the heroines of the novels: Fanny Price in Mansfield Park, Marianne Dashwood in Sense and Sensibility, Elizabeth Bennet in Pride and Prejudice, Jane Fairfax in Emma, Catherine Morland in Northanger Abbey and Anne Elliot in Persuasion. Emphasis is on Mansfield Park.

\section{The Journey}

The Romantics discover that many of this "solitary" or "wandering Jew", whether they be rebels like Cain or men of God like 'Vigny's Moses ... are shown to suffer the same despair, namely, "the self .... Whose worm dieth not, and whose fire is not quenched" (Hartman 2006, 139)

The entrance of a young woman into this world, or the journey of perilous search is explained in more details in Mansfield Park than in her other novels. The heroine Fanny Price was the subject of discussion among her cousins and friends and the question of her being "out" became a thing of debate. Miss Crawford observes the manner of the coming "out" of ladies, their manners before and after coming out, and the consequences. Austen observes that the woman is always not prepared and does not adjust to the world on her coming out. It usually is difficult for her. "The most objectionable part is, that the alteration of manners on being introduced into company is frequently too sudden ... that is the faulty part of the system. One does not like to see a girl of eighteen or nineteen so immediately up to everything perhaps when one has seen her hardly able to speak the year before." (p. 502). Austen describes Fanny's coming "out":

Miss Price ... was now to make her first appearances, and must be regarded as the queen of the evening. Who could be happier than Miss Price? But Miss Price had not been brought up to the trade of coming out; and had she known in what light this ball was, in general, considered respecting her, it would very much have lessened her comfort by increasing her fears she already had of doing wrong and being looked at. (p. 637)

In the other novels we encounter the other heroines already out and are facing their individual challenges. Hartman (2006) explains Kleist's reflection and Hegel's interpretation of the fall and "argues that the way back to Eden is via contraries: the naively sensuous mind must pass through separation and selfhood to become spiritually perfect" (p. 138). In her search of the outward model that completes her, the woman is faced with many models (nature) to choose from. For Austen, this choice presents her moral dilemma.

Fanny in Mansfield Park refuses to love a nature that she conceives to be corrupt in Mr. Crawford "I cannot like him, well enough to marry him" (p. 667). She believes that his 'nature is the source of all perverse pleasures' but couldn't tell her uncle so as not to implicate her cousins in his Maria and Julia in his guilt. Austen also portrays her heroines disregarding any external influence in the search and ultimate choice of the nature the unite with, for Fanny, she experiences the form of nature that please her, Fanny sees in Edmund, whom Austen directly refers to as "Nature" in her childhood days as an icon of perfection. "She loved him better than anybody in the world" (p. 485); except for her brother. As Fanny's relationship with Edmund continues, her inner world is also in the process of construction:

She regarded her cousin as an example of everything good and great, as possessing worth, which no one but herself could ever appreciate, and as entitled to such gratitude from her, as no feelings could be strong enough to pay. Her sentiments towards him were compounded of all that was respectful, grateful, confiding, and tender. (p. 494)

Anne rejects nature and pursues sensibility, at a later time in life found her way back to the nature she rejected and attain to her paradise. For Elizabeth she has to tame the defect of pride and arrogance in her nature and then accepts him. For Marianne, she had to experience the taste of a bad nature before she finally attaches herself to the good one and for Emma, she had to deal with self denial, then rejects the materialistic or rather corrupt nature before attaching to the good one, for Catherine, she had to grow strong to reject the nature that is corrupt and wants to impose himself by manipulation on her and then unite to the good one. Their experiences differ but their pursuit is the same.

Wordsworth describes nature as "a mother goddess who teaches the soul serenity and joy, and never betrays the heart that loves her. [And that] the reality of nature is manifested by its reflection of moral values", Marquis de Sade differs "nature is the source of all perverse pleasures" and the reality of nature are concealed by the reflection of moral values. (qtd. in Frye 2006, 133)

Nature therefore posses two forms of realities and can adequately express itself in both, Austen reflects both realities of nature in her presentation of the masculine dominance as stated above. Austen presents a scenario where "nature" 
becomes a source: either of good or bad. Even though the creative power of the woman is in the inside of her and the model she is supposed to imitate is inside, built up by experience, it is also outside. When the two, the inward and outside model meet, there is a unity, a union of two halves to form a whole either for elevation of otherwise.

For romanticism the cult of the primitive is a by-product of the internalization of the creative impulse the poet has always been suppose to be imitating nature, but if the model of his creative power is in his mind, the nature that he is to imitate is now inside him even if it is also outside. ... The sense of identity with a larger power of creative energy meets us everywhere in romantic culture (Frye 2006, 129).

The inward model for Austen's heroine is embodied in their inward construct. They decide the kind of Eden they want to construct for themselves. Elizabeth and Charlotte have variance in disposition and their view on the manner of influence to assert on a man to win a commitment to marriage differs. This difference is very significant as it illustrates clearly that the creative power of the artist (the woman), and indeed mankind is in the inner construct shaped by experience. Elizabeth's age and experience in life differs from that of Charlotte. While Elizabeth is loved and respected by her father and considered special and with great sense, Charlotte at twenty seven is considered by her family as an old maid who has no possible future in marriage and her younger sisters see her as preventing them from coming "out". Sir Thomas Bertram connects to the point of experience when he saw the difference in his niece Fanny and his two daughters who had more comfort and education than she had, he "Acknowledge the advantages of early hardship and discipline and the consciousness of being born to struggle and endure” (p.767).

All the heroines encounter two kinds of nature to choose from. For Fanny it was Mr. Crawford and Edmund, for Anne it was Mr. Elliot and Captain Wentworth, for Marianne it was Mr. Willoughby and Colonel Brandon, for Elizabeth it was Mr. Collins and Mr. Darcy, for Catherine is John Thorpe and Mr. Tilney, for Emma it was Mr. Elton and Mr. Knightley. The significance of choice is the emphasis of the moral dilemma evident in the journey to or search of the paradise lost. The natures represented or symbolized by the male characters mentioned represent the bad and the good respectively, while the former natures symbolize bad, the later ones symbolize good. The heroines choose the good nature and were married. The entered into their paradise are seen cultivating it with joy.

The Romanticism poets fall back to the language and story of religion to effectively and efficiently express their experiences. Austen in this discourse has sufficiently manifested her ability to use this tool effectively in her symbolic expressions of the cyclical nature of the journey of humanity which ends ultimately at where it started, at a higher level. The journey itself is the centrality of her expressions, 'the wandering Jew' suggest an endless journey of which has been adequately explored by Austen in the different female characters in her novel, she paints a picture of wanderers, young hearts searching for completeness. The concept of wandering, pursuing the quest for an organic whole, which her heroines achieved through their marriage to nature is achieved in the narration.

The process of creation becomes terminated only at the death of the artist (God, nature or mankind who is the artist and creator). At the point of death of Mr. Dashwood or Mrs. Churchill their influence, significance or creativity becomes extinct. Mr. Dashwood tries to provide a better life for his daughters in the aspect of financial independence but fails to do so because he died. The creative model dies along with the creator or is extinct at the point of his death. Mrs. Churchill, just like Mr. Dashwood has great influence in her Eden (home) but she too like Mr. Dashwood lost all that at the point of death. Mrs. Weston marvels at the power of death

Conceive what the events of a week have done in that family! While poor Mrs. Churchill lived, I suppose there could not have been hope, a chance, and a possibility; but scarcely are her remains at rest in the family vault, than her husband is persuaded to act exactly opposite to what she would have required. What a blessing it is, when undue influence does not survive the grave! He gave his consent with very little persuasion (p. 1015).

This kind of Influence, Elizabeth taught her sister-in-law Georgiana, who is amazed at the liberty she takes with her husband. Elizabeth tells Georgiana whose 'mind received knowledge which had never before fallen in her way. By Elizabeth's instructions she began to comprehend that a woman may take liberties with her husband.' (p. 472), the union of two hearts creates a whole and liberty and freedom is explored and a healing process becomes complete.

\section{References}

Abrams, M. H. (2006) English Romanticism: The Spirit of the Age. Romanticism: Critical Concept in Literary and Cultural Studies, Definitions and Romantic Form 1: 74 - 101.

Deresiewicz, William. (2004). Jane Austen and the Romantic Poets. New York: Columbia University Press.

Frye, Northrop. (2000). Anatomy of Criticism. Princeton and Oxford: Princeton University. Press.

(2006) The Drunken Boat: The Revolutionary Element in Romanticism. Romanticism: Critical Concept in Literary and Cultural Studies, Definitions and Romantic Form 1: 122 - 135.

Hartman, Geoffrey. (2006). Romanticism and Anti - Self - Consciousness. Romanticism: Critical Concept in Literary and cultural Studies Definitions and Romantic Form 1: 136 - 145.

Irvine, P. Robert. (2005). Jane Austen. London: Taylor and Francis Group.

Loades, David. (2009). The Tudor Queens of England. London: Continuum UK. 
Lovejoy, Arthur O. (2006) On the Discriminations of Romanticisms. Romanticism: Critical Concept in Literary and Cultural Studies, Definitions and Romantic Form 1: 36-55. Print.

Richardson, Alan. (2006). Of Headache and Head Injury: Minds, Brains, and the Subject of Persuasion. Romanticism: Critical Concept in Literary and Cultural Studies, Romanticism and History II: 301-321.

Rosen, Charles. (2006). The Intense Inane: Religious Revival in English, French, and German Romanticism: M. H. Abrams, William Empson. Romanticism: Critical Concept in Literary and Cultural Studies, Romanticism, Belief and Philosophy IV: 19-33.

Tauschert, Ashley. (2005). Romancing Jane Austen: Narrative, Realism and the Possibility of a Happy Ending. New York: Palgrave Macmillan.

Thomas, Helen. (2006). Romanticism and abolitionism: Mary Wollstonecraft, William Blake, Samuel Taylor Coleridge and William Wordsworth." Romanticism: Critical Concept in Literary and Cultural Studies, Romanticism and History II: 253-297.

Wainwright, Valarie. (2007). Ethics and the English Novel from Austen to Forster. England: Ashgate Publishing Limited.

Wordsworth Editions. (2004). The Complete Works of Jane Austen. London: Hertfordshire. 